\title{
FERTIGATION MANAGEMENT TO MAXIMIZE OLEUROPINE CONTENT IN OLIVE LEAVES
}

\author{
F. A. A. Hassan, ${ }^{*}$ A. H. Abd-Elaty ${ }^{*}$ and A. A. Abd-Elmonsef ${ }^{*}$
}

\begin{abstract}
This study was conducted for three successive seasons (2015/2016/2017) on Chemlali olive trees 15 year's old at a private orchard, located on the $32 \mathrm{~km}$ Cairo-Alexandria desert road. The main aim of the present research is to study the effect of irrigation system (dripper and bubbler); deficit irrigation regimes "DIR" (75\% and $50 \%$ ETc.) and 4 additional doses of urea by two rates of dose (200 $\mathrm{gm}$ and $400 \mathrm{gm})$, injected throughout irrigation system, with a rate of (1 kg./100 l), during March, on vegetative growth " number of new shoots; shoot length; shoot diameter; number of leaves per shoot and leaf area"; fruit yield; alternative bearing index and Oleuropein concentration in the olive leaves. The following treatments were applied: T1: control (100\% ETc. by drip with recommended fertilization rate); T2 (50\% of ETc. by drip + $0.8 \mathrm{~kg}$ urea/tree); T3 (50\% of ETc. by drip + $1.6 \mathrm{~kg}$ urea/tree); T4 (75\% of ETc. by drip + $0.8 \mathrm{~kg}$ urea/tree); 75 (75 of ETc. by drip+1.6 kg urea/tree) T6 (50\% of ETc. by bubbler $+0.8 \mathrm{~kg}$ urea/tree); T7 (50\% of ETc. by bubbler $+1.6 \mathrm{~kg}$ urea/tree); $T 8$ (75\% of ETc. by bubbler +0.8 $\mathrm{kg}$ urea/tree) and T9 (75\% of ETc. by bubbler+1.6 kg urea/tree). The results indicated that, all parameters of the vegetative growth and fruit yield increased by using bubbler 100l/h and applying the proposed DIR with additional doses of urea. The highest value of alternative bearing index was 0.256 recorded with control treatment (T1). Meanwhile the lowest alternate bearing index was 0.131 recorded with (T9). Oleuropein concentration in the olive leaves increased with all tested treatments compared with (T1), the lowest value of Oleuropein content was 58 (mg/lo0gm) obtained under the control treatment (T1). The highest values of Oleuropein content were 316.59 ( $\mathrm{mg} / 100 \mathrm{gm})$ obtained with (T9).
\end{abstract}

* Ag. Eng. Res. Inst., Ag. Res. Center, Dokki, Giza, Egypt. 
Thus, applying DIR $75 \%$ ETc. with 4 additional doses of urea (400 gm for each) during March by using bubbler system, with saving 25\% of irrigation water, will improve vegetative growth and reduce the severity of alternative bearing, as well as increase the Oleuropein concentration in the olive leaves.

Key words: Olive trees; deficit irrigation regime; dripper; bubbler; fertigation; Olive leaves; vegetative growth; alternative bearing index and Oleuropein concentration.

\section{INTRODUCTION}

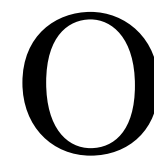
live tree (Olea europaea L.) is one of the most important fruit trees in Mediterranean countries, where they cover 8 million ha, accounting for almost $98 \%$ of the world crop. This demonstrates the great economic and social importance of this crop and the possible benefits to be derived from utilization of any of its by-products, Guinda et al. (2004) \& Tabera, et al. (2004). The Egyptian olive production reached about 698,927 ton produced from 227,683 feddan with (168 trees/feddan), M.A.L.R (2015). Although, the Ministry of Agriculture plans to cultivate one million new olive trees in Sinai, most owners of olive orchards especially at Cairo-Alexandria desert road decided to remove those orchards and replanting with other more profitable fruit trees due to the poor yielding. Where Olive is notorious alternate bearing $(\mathrm{AB})$ which characterize by high crop in one year (On-year) and low or no crop in subsequent year (Off- year). $A B$ is variety specific, but influenced by the growing environment (climate and soil) and horticultural practices which may increase or reduce the severity of $A B$ or may lead the trees to enter the cycle of this phenomena, Cimato and Fiorino (1986). Several trails were carried out to study the use of different plant growth regulators for the control of flower and fruit numbers on olive tree, so as to diminish the AB, Cuevas et al. (1994). Extensive olive cultivation, characterized by the irregular supply of water and particularly nutrients, is considered to be one of the reasons for the high fluctuations in olive yield, Barranco et al. (1998). In advanced intensive cultivation of olives, based on fertigation technology, the 
continuous application of nutrients is addressed far well than in traditionally cultivated olive groves. Some studies in recent years have clearly demonstrated the effect of a novel foliar nutrient system, applied just before the olive blooms at the beginning of the spring in significantly increasing the olive yield in both "on" and "off" years, Wiesman et al. (2002, c \& d). Troncoso et al. (1997) Observed after eight years of $2 \mathrm{~kg}$ of urea $(46 \%)$ per tree fertigation, an increase on vegetative growth and yield in 25-years-old 'Manzanilla de Sevilla' trees, while fruit weight was not affected. Olive has been traditionally grown rain-fed conditions and is considered one of the best adapted species to the semi-arid environment, Giménez, et al. (1997). However, under this condition it usually shows a decrease in photosynthesis that limits growth and yield, Bongi, G. and A. Palliotti (1994). Most research work dealing with irrigation of olive orchards showed that trees respond favorably and quickly even when low volumes of water are applied, Aïachi et al. (2007 and 2008); Masmoudi-Charfi and Ben Mechlia, (2007 and 2008). Furthermore, supplying trees with suitable amounts of water, given at precise stages of tree and fruit development, provide a better control of nutrients and carbohydrate's distribution, leading to more regular yields, Fernandez and Moreno, (1999); D‘Andria et al.( 2008); Iniesta et al. (2009); Palese et al., (2010). Several methods, approaches and concepts were developed during the last decade, in order to determine more precisely the amount of water requested by trees for their growth and production, Palomo et al., (2002); Fernandez (2006). The current trend in the irrigation of olive trees is to develop either sustained deficit irrigation (SDI) or regulated deficit irrigation (RDI) strategies, whereby the water is applied at a rate less than the needs of evapotranspiration with only very small reductions in yield, Goldhamer (1999); Tognetti et al. (2005). Under conditions of scarce water supply and drought, SDI and RDI irrigation regimes at selected phonological phases, can lead to greater economic gains than simply maximizing yields per unit of water as shown by Tognetti et al. (2006). However, they cautioned this approach requires precise knowledge of crop responses to water stress at specific physiological stages. The term of "olive leaves" refers to a mixture of leaves and branches, are one the by-products of farming of the olive 
grove. Olive leaves can be found in large amounts in the olive oil industries (10\% of the total weight of the olives) and they accumulate during the pruning of the olive trees (about $25 \mathrm{~kg}$ of by-products (twigs and leaves) per tree annually), Herrero et al. (2011). The leaf is the primary site of plant metabolism, at the level of both primary and secondary plant products Antolovich, et al. (2000) and can be considered as a potential source of bioactive compounds, Tsimidou, and Papoti (2010). The main category of those compounds is secoiridoids that are present in Oleaceae and other few dicotyledonus plant families, Alagna et al. (2012). One of the most dominant secoiridoid found in olive leaves is oleuropein, Sahin et al. (2012). Oleuropein in the olive leaves varies from $17 \%$ to $23 \%$ depending upon the harvesting time of the leaves, Le Toutour, and Guedon (1992). Olive leaves also contain other bioactive phenolics like phenyl ethyl alcohols (tyrosol and hydroxytyrosol), simple phenols (caffeic acid, p-coumaric acid, vanillic acid, vanilin, etc.) and flavonoid-like compounds (verbascoside, luteolin, diosmetin, rutin, luteolin-7-glucoside, apigenin-7-glucoside and diosmetin-7-glucoside, etc.), Vissers et al. (2004); Lee et al. (2009); Hayes et al. (2011) and Ahmad-Qasem et al. (2013). All these compounds could be of interest to the pharmacological, nutraceutical, cosmetic, and food industries. Therefore, the rational use of olive tree waste materials could have perspective future, Peralbo-Molina and Luque de Castro (2013). Olive leaf was first used medicinally in Ancient Egyptian and was symbol heavenly power. A few decades later green olive leaves were used in tea as a treatment for malaria, Somova et al. (2003); science then several researcher demonstrated antiviral, Micol et al. (2005); anti-HIV; antimicrobial, Bisignano et al. (1999); antioxidant and antiinflammatory, Briante et al. (2002); and anti-carcinogenic properties that lead to the prevention of some cancers, Owen et al. (2004). And finally stimulation of the thyroid activities of olive leaf extracts Al-Qarawi et al. (2002). Oleuropein, a bitter-tasting secoiridoid glycoside present in olive leaves, is suggested to support hypotensive activity, have preserving activity against lung cancer, colorectal, pharyngeal and esophagus cancer, Uccella and Saija (2001). The hypothesis of this study was that, to compensate the reduction of olive fruit yield, during off year season 
due to $A B$, using a suitable irrigation system and applying deficit irrigation regime (DIR) with timely doses of urea (at March), will improve the vegetative growth; reduce the severity of $\mathrm{AB}$ and increase olive leaves contents of Oleuropein.

The main objective of this research was to study the effect of irrigation system (dripper and bubbler) and applying different deficit irrigation regimes ( $50 \%$ and $75 \%$ ETc.) with additional doses of urea, on the vegetative growth; fruit yield and alternative bearing index as well as the concentration of Oleuropein in olive leaves.

\section{MATERIALS AND METHODS}

\subsection{Experimental site:}

This study was carried out during three successive seasons, (2015/2016/2017) at a private orchard located on the $32 \mathrm{~km}$ from CairoAlexandria desert road (30.077905, 30.999313), on olive trees (Olea. europaea L. $c v$ Chemlali) 15 years old cultivated at spacing of $0 \times 5 \mathrm{~m}$ under semi-arid conditions in a sandy soil. The orchard soil and irrigation's water weal analysis are given in (Table 1 and 2) according to procedures which are outlined by, Wild et al. (1985). The selected trees were uniform in shape; vigor; size; normal growth and were going to an expected "off year" and received regular horticultural practices such as irrigation; fertilization; pruning; hoeing and pest or fungi control management that were carried out in the Chemlali olive orchards. The site is characterized by hot or worm in summer and cool in winter, with an average temperature in winter and summer of $14^{\circ} \mathrm{C}$ and $30^{\circ} \mathrm{C}$ respectively, and receives less than $80 \mathrm{~mm}$ of precipitation annually as in most areas of Egypt, FAO (2011).

\subsection{Experimental material}

\subsubsection{Irrigation and Fertilization Management:}

- To determine the best fertigation management plan that can be applied when expecting off year season, to decrease the severity of $A B$ and compensate the reduction on fruit yield by stimulate the tree to increase vegetative growth and Oleuropein content in Olive leaves. This study carried out at one feddan experimental area " $120 \times 35 \mathrm{~m}^{2}$ " cultivated with 168 trees ( 24 rows with 7 trees for each), divided into two main plots (84 trees) at 12 rows. 
Table 1: Physical and chemical analysis of the soil at the experimented orchard.

\begin{tabular}{|c|c|c|c|}
\hline Character & Value & Character & Value \\
\hline \multicolumn{4}{|c|}{ Pore size distribution $(\%)$} \\
\hline Coarse Sand & $40-74$ & $\mathrm{EC}(\mathrm{ds} / \mathrm{m})$ & 0.38 \\
\hline Fine Sand & $54-79$ & $\mathrm{pH}$ & 9.2 \\
\hline Silt + clay & 4.74 & Organic matter & 0.57 \\
\hline Textural class & Sandy & $\mathrm{CaCO} 3$ & \\
\hline \multicolumn{2}{|c|}{ Soluble Cations (meq/l) } & \multicolumn{2}{|c|}{ Soluble Anions (meq/l) } \\
\hline $\mathrm{Ca}$ & 1.25 & $\mathrm{HCO}_{3}$ & 1.18 \\
\hline $\mathrm{Ma}$ & 0.60 & $\mathrm{Cl}$ & 1.80 \\
\hline $\mathrm{Na}$ & 1.60 & $\mathrm{SO}_{4}$ & 0.75 \\
\hline $\mathrm{K}$ & 0.20 & & \\
\hline
\end{tabular}

Table 2: Chemical analysis of water weal used at the experimented orchard.

\begin{tabular}{|l|c|c|c|c|c|c|c|c|c|}
\hline \multirow{2}{*}{ EC } & \multirow{2}{*}{$\mathrm{pH}$} & \multicolumn{3}{|c|}{ Soluble cations (meq/l) } & \multicolumn{4}{c|}{ Soluble anions (meq/l) } \\
\cline { 3 - 10 } & & $\mathrm{Ca}$ & $\mathrm{Ma}$ & $\mathrm{Na}$ & $\mathrm{K}$ & $\mathrm{CO} 3$ & $\mathrm{Hco}$ & $\mathrm{Cl}$ & $\mathrm{SO} 4$ \\
\hline 0.95 & 7.5 & 1.50 & & 5.10 & 0.40 & 0.0 & 2.1 & 4.90 & 2.5 \\
\hline
\end{tabular}

The $1^{\text {st }}$ main plots irrigated with bubbler $100 \mathrm{l} / \mathrm{h}$ (one bubbler /tree) and the other fitted with a line of dripper's along the trees, four emitters $81 / \mathrm{h}$ per tree, being two of them on each side of the tree $1 \mathrm{~m}$ apart from each other. Each main plot divided into two sub plots (42 trees) at 6 rows, the $1^{\text {st }}$ sub plots subjected to deficit irrigation regime (DIR) $50 \%$ ETc. and the other $75 \%$ ETc. Each sub plot divided into two sub sub plots (21 trees) at 3 rows. The $1^{\text {st }}$ sub sub plots injected by additional 4 doses of urea $200 \mathrm{gm}$ and the other injected by $400 \mathrm{gm} /$ tree during March. The system included a main valve, a main water meter, a pressure regulator, pressure gauges, and a 120 mesh in 2 disk filter. Each lateral was equipped with a valve to stop and/or control water flow at any time and with water meters to measure the desired water flow according to the irrigation schedule, as well as venture type injector to supply the nutrients solution only to the experimental trees. Irrigation pipes and disk filters were flushed weekly to avoid clogging of any of the orifices.

- According to Salama et al. (2016) the recommended irrigation and fertilization for olive tree fruit yield production by Min. of Agric. Egypt, was that, irrigation rate" $100 \%$ ETc." = $2526 \mathrm{~m}^{3} /$ faddan/year. 
Meanwhile fertilization rates divided into three doses applied at January (before flowering) as NPK; June (after fruits set) as NK and August (after pit hardening) as NK, mixed with the soil surface layer $(20 \mathrm{~cm}$ depth) surrounding the trunk at the external end of canopy shade. The olive trees required actual nitrogen $(1 \mathrm{~kg} /$ tree /year $)$ equal $5 \mathrm{Kg}$ ammonium sulfate $(20.6 \% \mathrm{~N})$ or $3 \mathrm{~kg}$ ammonium nitrate $(33.3 \% \mathrm{~N})$. Mineral phosphate fertilizer was added by rate $1.75 \mathrm{Kg}$ of super phosphate $(15.5 \% \mathrm{P} 2 \mathrm{O} 5)$ per tree. In addition, $1.50 \mathrm{Kg}$ of potassium sulfates $(48 \% \mathrm{~K} 2 \mathrm{O})$ per tree was added as a soil application divided into two equal doses, at the $2^{\text {nd }}$ week of December combined with phosphate. Table (3) shows the average amount of irrigation water $\left(\mathrm{m}^{3} / \mathrm{fed}\right)$ applied monthly with different deficit regime during annual growing season.

Table (3): Average amount of water applied $\left(\mathrm{m}^{3} / \mathrm{fed}\right)$ during annual growing season.

\begin{tabular}{|l|c|c|c|}
\hline \multirow{2}{*}{ Months } & \multicolumn{3}{|c|}{ Amount of water applied (m3/fed) } \\
\cline { 2 - 4 } & $100 \%$ ETc & $75 \%$ ETc & $50 \%$ ETc \\
\hline January & 67.2 & 50.4 & 33.6 \\
\hline February & 67.2 & 50.4 & 33.6 \\
\hline March & 161.28 & 120.96 & 80.64 \\
\hline April & 161.28 & 120.96 & 80.64 \\
\hline May & 403.2 & 302.4 & 201.6 \\
\hline June & 403.2 & 302.4 & 201.6 \\
\hline July & 403.2 & 302.4 & 201.6 \\
\hline August & 403.2 & 302.4 & 201.6 \\
\hline September & 161.28 & 120.96 & 80.64 \\
\hline October & 161.28 & 120.96 & 80.64 \\
\hline November & 67.2 & 50.4 & 33.6 \\
\hline December & 67.2 & 50.4 & 33.6 \\
\hline Total amount & 2526 & 1895 & 1263 \\
\hline Saving amount & & $25 \%=631.68 \mathrm{~m}^{3}$ & $50 \%=1263.36 \mathrm{~m}^{3}$ \\
\hline
\end{tabular}

\subsubsection{Experimental design:}

The treatments will be arranged in a split split plot design (SSPD), where the irrigation method at the main plot; the irrigation regime at the sub plot and the doses of urea at sub sub plot. Data were statistically 
processed with Excel 2010 program. Table (4) shows the applied treatments for each plot.

Table 4: Experimental applied treatments:

\begin{tabular}{|l|l|l|l|}
\hline Treatments & $\begin{array}{l}\text { Irrigation } \\
\text { system }\end{array}$ & $\begin{array}{l}\text { Water regime } \\
\text { level \% ETc. }\end{array}$ & $\begin{array}{l}\text { Fertilization } \\
\text { (kg/tree) }\end{array}$ \\
\hline T1* & Control & $100 \%$ & ---- \\
\hline T2 & drip & $50 \%$ & $0.8 \mathrm{~kg}$. \\
\hline T3 & drip & $50 \%$ & $1.6 \mathrm{~kg}$. \\
\hline T4 & drip & $75 \%$ & $0.8 \mathrm{~kg}$. \\
\hline T5 & drip & $75 \%$ & $1.6 \mathrm{~kg}$. \\
\hline T6 & bubbler & $50 \%$ & $0.8 \mathrm{~kg}$. \\
\hline T7 & bubbler & $50 \%$ & $1.6 \mathrm{~kg}$. \\
\hline T8 & bubbler & $75 \%$ & $0.8 \mathrm{~kg}$. \\
\hline 9T & bubbler & $75 \%$ & $1.6 \mathrm{~kg}$. \\
\hline
\end{tabular}

* T1: control treatment (21 trees) selected randomly from the remaining orchard trees outside the experimental area, that receiving only the recommended irrigation and fertilization rates.

\subsubsection{Treatments:}

- Two types of irrigation system: dripper (8 1/h) and bubbler (100 l/h);

-Three level of deficit irrigation regime:

1- $100 \%$ ETc. $=2526 \mathrm{~m}^{3} /$ feddan/year (control);

2- $75 \%$ ETc. of water irrigation required $\left(1895 \mathrm{~m}^{3} /\right.$ faddan/year $)$;

3- $50 \%$ ETc. of water irrigation required $\left(1263 \mathrm{~m}^{3} /\right.$ faddan/year $)$;

and

- Two additional doses of urea:

1 - $(0.8 \mathrm{~kg} /$ tree $)$ and

2- (1.6 kg /tree); Distributed at 4 doses of (200 gm or $400 \mathrm{gm}$ for each); injected during March, through irrigation system with a mixing rate of ( $1 \mathrm{~kg} / 100$ liter).

\subsection{Measurements and Analysis:}

On early January of each season, twenty healthy one year old shoots, well distributed around periphery of each tree were randomly selected and labeled for carrying out the following measurements.

\subsubsection{Vegetative Growth:}

At the end of each growing season during first week of September, four branches on all direction were chosen and labeled in each tree. The vegetative parameters were measured and determined as the following. 
a. Number of new shoots (current season growth). b. Shoot length $(\mathrm{cm})$.

c. Shoot diameter (mm). d. Number of leaves per shoot. e. Leaf area $\left(\mathrm{cm}^{2}\right)$. Calculated according to (Ahmed and Morsy, 1999) by using the following equation:

Leaf area $=0.53$ (length $x$ width $)+1.66$.

\subsubsection{Yield:}

Olives were start harvested at mid-September every season when about $75 \%$ of the olives reached mature stage, fruits of each tree were separately harvested, then weighed and yield was estimated as $\mathrm{Kg} /$ tree.

\subsubsection{Alternative bearing Index (ABI):}

From the recorded yield for each tree through three seasons, the ABI was calculated by using the following equation according to Pearce et al. (1967).

$A B I=(1 / n-1)\left(\left(a_{2}-a_{1}\right) /\left(a_{1}+a_{2}\right)+\left(a_{3}-a_{2}\right) /\left(a_{2}+a_{3}\right)+\left(a_{n}-a_{n-1}\right) /\left(a_{n-1}+a_{n}\right)\right) \ldots(2)$

Where: $\mathbf{n}$ : is the number of years of evaluation

$\mathbf{a}_{1}, \mathbf{a}_{2}, \mathbf{a}_{3}, \ldots \mathbf{a}_{\mathrm{n}-1}$ are the fruit production per tree (kg/tree) which were measured in the respective period of analysis (seasons of 2015 to 2017).

\subsection{Determination of Oleuropein in Olive leaf extracts by HPLC.}

Oleuropein concentration in the olive leaves extract, determined by using HPLC instrument. Samples were prepared according to the method described by Jakopič et al. (2009). Olive leaves samples were obtained from trees localized in the sunshine area, collected directly from the trees in the middle of November 2016. Fresh olive leaves were dried at ambient temperature, and grinded to obtain olive fine powder which was stored at room temperature in dark until extraction. $100 \mathrm{mg}$ of the sample was measured into a test tube. Weights of samples were extracted with 10 $\mathrm{ml}$ methanol in ultrasonic bath for 45 minutes. Then the samples were centrifuged for 7 minutes at $4200 \mathrm{rpm}$. The supernatant was filtered through polyamide filter Chromafil AO-45/25, transferred into vial prior analyses. All chromatograms were plotted at $280 \mathrm{~nm}$ to estimated phenolic acids and at $330 \mathrm{~nm}$ for flavonoids. All components were identified and quantified by comparison of peak areas with external standards, Schieber et al. (2001). All processes of samples preparation and analysis carried out at the lab of Food Technology Research Institute. 


\section{RESULTS}

(1) Effect of irrigation system; deficit irrigation regime and additional doses of urea, on vegetative growth characteristics.

(a) Number of new shoots (current season growth).

Fig. ( 1 a): shows the effect of irrigation system; deficit irrigation regime "DIR" and additional doses of urea, on the number of new shoots. The maximum values of number of new shoots were $17.67 ; 16.71 ; 16.68$ and 14.71 recorded with treatments T9, T8, T7 and T6. Meanwhile the minimum number of shoots was 10,29 recorded with control treatment T1 through 2017. The previous results were at the same trend.

(b) Shoot length (cm).

Fig. (1 b): shows the effect of irrigation system; deficit irrigation regime DIR and additional doses of urea on shoot length. The maximum values of shoot length were 27.52 and $26.58 \mathrm{~cm}$ recorded with treatments T9 and T7. Meanwhile the minimum value of shoot length was $23.61 \mathrm{~cm}$ recorded with treatment $\mathrm{T} 1$ through 2017 , the previous results were at the same trend.

\section{(c) Shoot diameter (mm).}

Fig. (1 c): shows the effect of irrigation system; deficit irrigation regime DIR and additional doses of urea, on shoot diameter. The maximum values of shoot diameter were 2.65 and $2.57 \mathrm{~mm}$ recorded with treatments T9 and T7. Meanwhile, the minimum value of shoot diameter was 2,19 $\mathrm{mm}$ recorded with treatment $\mathrm{T} 1$ through 2017, the previous results were at the same trend.

\section{(d) Number of leaves per shoot.}

Fig. (1 d): shows the effect of irrigation system; deficit irrigation regime DIR and additional doses of urea, on shoot length. The maximum values of number of leaves per shoot were 35.5 and 33.0 recorded with treatments T9 and T7. Meanwhile, the minimum value of number of leaves per shoot was 25.34 recorded with treatment T1 through 2017, the previous results were at the same trend.

(e) Leaf area $\left(\mathrm{cm}^{2}\right)$.

Fig. (1 e): shows the effect of irrigation system; deficit irrigation regime DIR and additional doses of urea, on leaf area $\left(\mathrm{cm}^{2}\right)$. The maximum values of leaves area were $5.31 \mathrm{~cm}^{2}$ and $5.11 \mathrm{~cm}^{2}$ recorded with 
treatments T9 and T7. Meanwhile, the minimum value of leaves area was $3.69 \mathrm{~cm}^{2}$ recorded with treatment $\mathrm{T} 1$ through 2017 , the previous results were at the same trend.

(a)

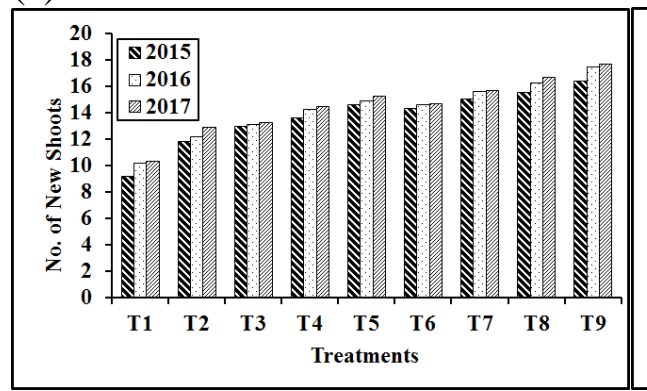

(c)

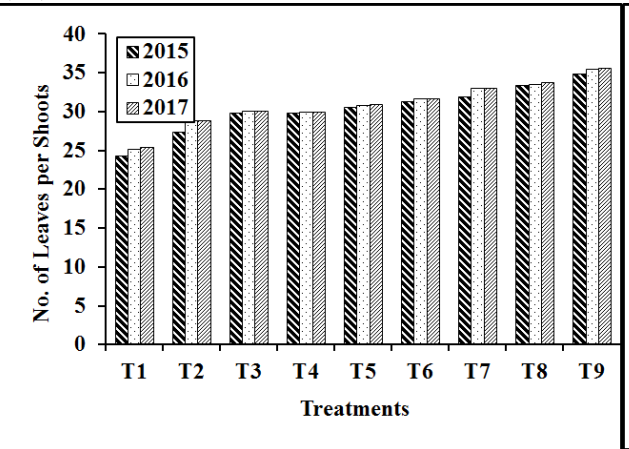

(b)

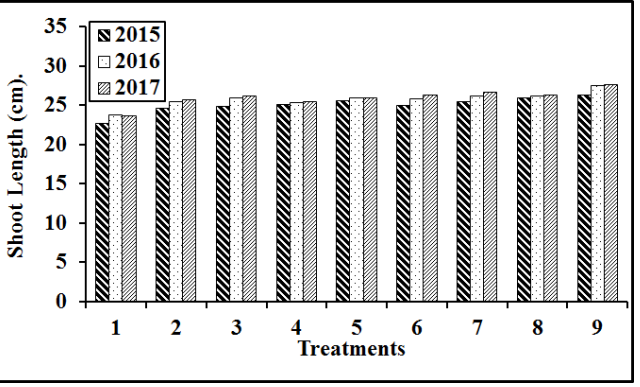

(d)

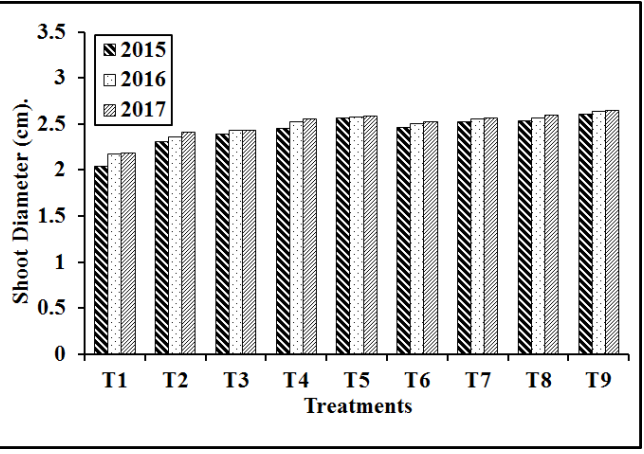

(e)

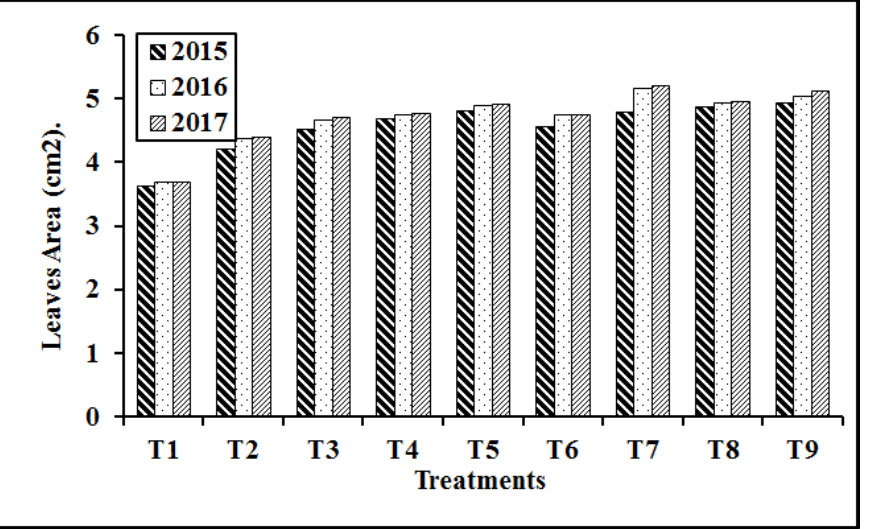

Fig. (1): Effect of irrigation system; deficit irrigation regime and additional dose of urea, on (a) number of new shoot (b) shoot length, (c) shoot diameter, (d) number of leaves per shoot and (e) leaf area $\left(\mathrm{cm}^{2}\right)$. 
(2) Effect of irrigation system; deficit irrigation regime and additional doses of urea on fruit yield.

Fig. (2): shows the effect of irrigation system; deficit irrigation regime (DIR) and additional doses of urea, on fruit yield $(\mathrm{kg})$. The maximum values of yield were $31.16 \mathrm{~kg}$ recorded with treatments T9. Meanwhile, the minimum value of yield was $15.61 \mathrm{~kg}$ recorded with treatment $\mathrm{T} 1$ through 2015. On the other hand, the highest value of yield at 2017 was $52.84 \mathrm{~kg}$ recorded also with treatments T9. Meanwhile, the lowest yield value at 2017 was $44.61 \mathrm{~kg}$ recorded with $\mathrm{T} 1$. This result revealed that, the fruit yield at 2015 was very week (off year) for all treatments compared with 2016 and 2017.

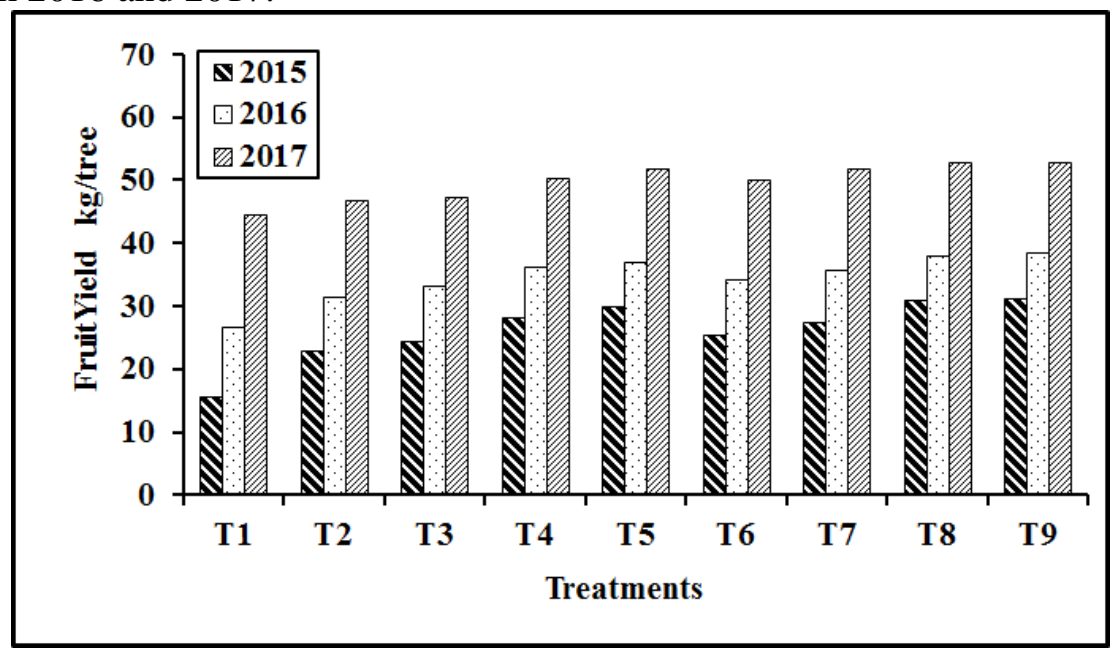

Fig. (2): Effect of irrigation system; deficit irrigation regime and additional doses of urea, on fruit yield.

(3) Effect of irrigation system; deficit irrigation regime and additional doses of urea on alternative bearing index.

Fig. (3): shows the effect of irrigation system; deficit irrigation regime and additional doses of urea, on alternative bearing index. The highest value of alternate bearing index was 0.256 recorded with control treatment (T1). Meanwhile, the lowest alternate bearing index was 0.131 recorded with (T9). 


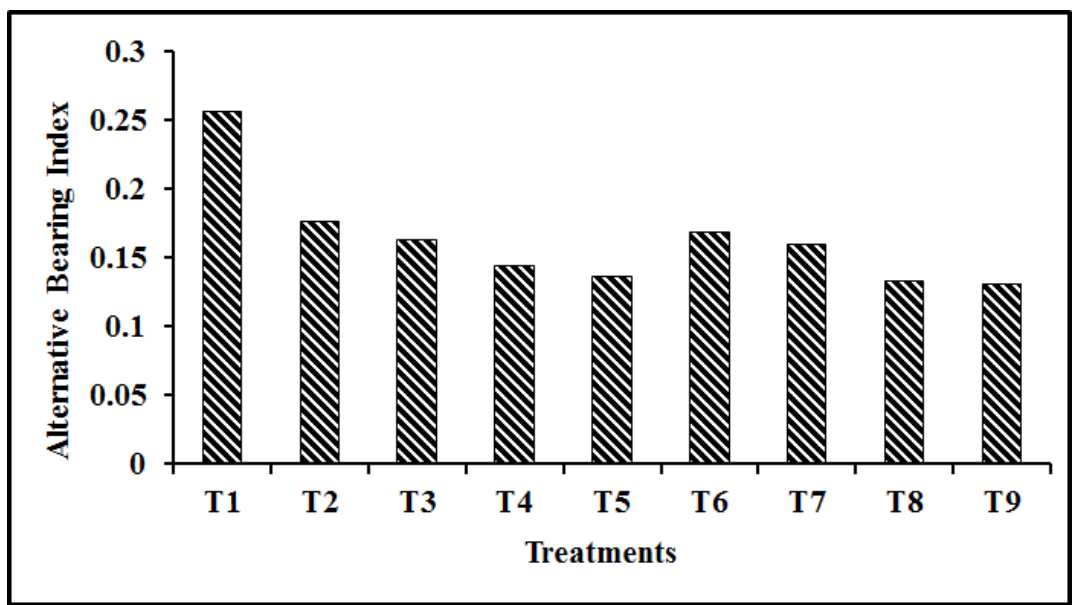

Fig. 3: Effect of irrigation system; deficit irrigation regime and additional doses of urea on alternative bearing Index.

(4) Effect of irrigation system; deficit irrigation regime and additional doses of urea, on Oleuropein concentration in olive leaves.

Fig, (4): shows the Oleuropein concentration in olive leaves extract obtained with all treatments.The maximum level of Oleuropein concentration in olive leaves extract was $316.59 ; 309.75$ and 297.70 $\mathrm{mg} / 100 \mathrm{~g}$ dry mater, recorded with treatments T9; T8 and T5 respectively. Meanwhile the minimum level of Oleuropein concentration was 58.56 $\mathrm{mg} / 100 \mathrm{~g}$ recorded with treatment $\mathrm{T} 1$ from samples taken through season 2016.

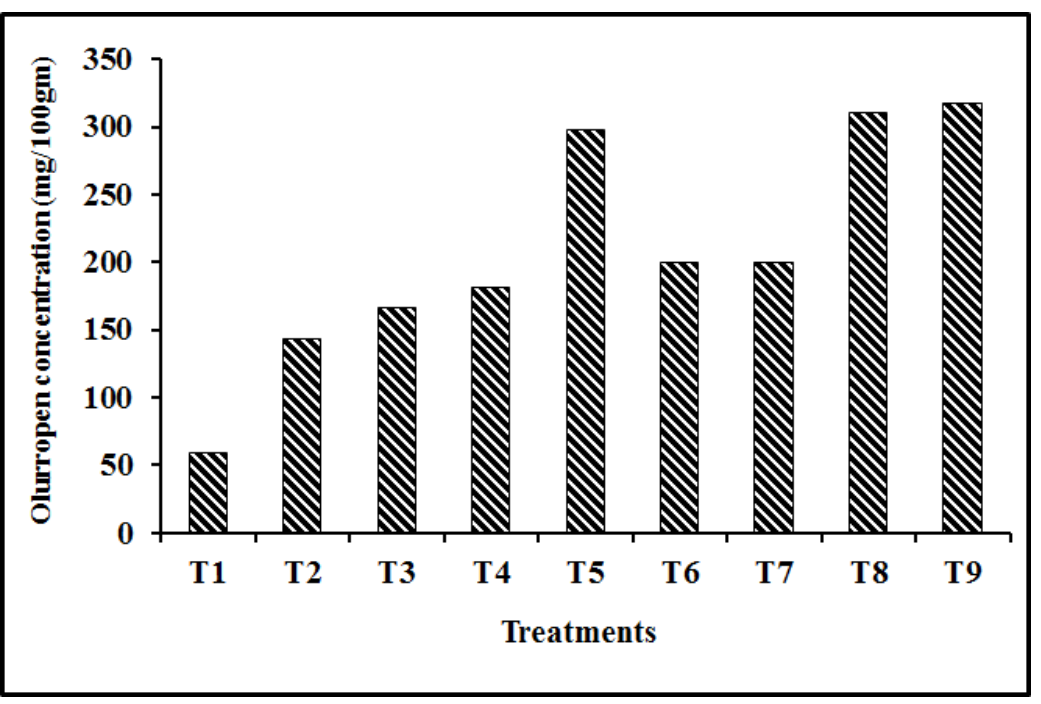

Fig, 4: Oleuropein concentration in olive leaves extract recorded with all treatments. 


\section{DISCUTION}

It is clearly noticed that, using bubbler $100 \mathrm{l} / \mathrm{h}$ and applying the deficit irrigation regime DIR of $75 \%$ ETc. with 4 additional doses of urea 400 $\mathrm{gm} /$ tree is beneficial for the olive tree vegetative growth and also fruit yield production, compared with the control treatment $\mathrm{T} 1$ and other treatments that apply DIR $50 \%$ ETc. by using dripper. As far alternate bearing index "ABI", the recorded value of ABI decreased with all treatments, compared with T1. On the other hand, Oleuropein concentration in the olive leave also increased when applying DIR of 75 $\%$ ETc. by using bubbler irrigation system with additional doses of urea $400 \mathrm{gm} /$ tree, compared with the control treatment T1. These results may due to that, bubbler system are particularly suited to irrigation fruit trees, specially the old olive trees (15 years), that has a deep root zone, in which a standpipe bubble can be installed alongside each tree. The irrigation water delivered by each bubbler is a big quantity in a short time distributed uniformly by filling small level basins, surrounded by low ridges, with equal quantities of water, and the ability to more precisely apply nutrients to the tree, made the bubbler system has an important role to develop deep root hairs, which improve all plant physiological activities, compared with drip irrigation system in which, the root development under drip irrigation is constrained to the wetted soil volume by the emission points, thereby roots are concentrated near the soil surface and their length is decreased, and slow down the plant physiological activity. DIR is an appropriate method of irrigation for olive trees that does not necessarily have any negative impact on fruit yield if applied during uncritical phonological stages with the correct amount of nitrogen fertilizer. So that, it's recommended that, using bubbler of $100 \mathrm{l} / \mathrm{h}$ and apply DIR $75 \%$ ETc. with $1.6 \mathrm{~kg}$ urea distributed in 4 doses during March will gave the highest level of vegetative growth and Oleuropein concentration in the olive leaves.

\section{CONCLUSION}

Conclusion from the previous results can be summarized as follows:

1- Managing the quantity and timing of irrigation and fertilization with olive trees, increases the yield of Oleuropein through enhancing the 
physiological activity of olive leaves, that will increases concentration of the phenolic compounds specially Oleuropein on the olive leaves, and also increase the amount of vegetative growth that can be harvested during trees pruning. This consider as an added value to the olive tree.

2- The best management plan for olive trees fertigation depends on the ultimate goal of production, whether that be for olive fruits or olive oil or newly for olive leaves. For the purpose of olive leaves production, the highest values of vegetative growth and olive leaves content's level of oleuropein achieved at DIR of $75 \%$ ETc. by using bubbler with additional 4 doses of urea (400gm), as in T9.

3- The availability of nitrogen considered the most important factor influencing primary and secondary metabolism syntheses in plants. A possible improvement of physiological performance of olive trees by increasing nitrogen levels.

4- When applying deficit irrigation regime of $75 \%$ ETc. a $25 \%$ cut in irrigation water use could be achieved without negative impacts on fruit yield production.

5- Olive leaves are a by-product of olive tree cultivation, available throughout the year; collected during pruning, harvest, and oil extraction. This biomass can be used as a cheap source of high addedvalue phenolic compounds; especially Oleuropein. It is a bioactive ingredient could be used in medicines, pharmaceuticals, cosmetics and to improve the shelf life of foods. Thus, valorization of olive leaves should be encouraged for replying higher demand of olive leaves for the pharmaceutical purposes inside Egypt and exporting outside.

6- More investigation effort must be carried to study the effect of DIR regime on the quality and quantity of olive oil production, and also Oleuropein concentration of olive leaves at different age and stages of crop cycle.

\section{REFERENCES}

Ahmed, F.F. and M.H. Morsy, 1999. A new method for measuring leaf area in different fruit species. Minia Journal of Agriculture and Development, (19): 97-105. 
Ahmad-Qasem, MH., Cánovas, J., Barrajón-Catalán, E., Micol, V, Cárcel, J.A., García-Pérez, J.V. (2013): Kinetic and compositional study of phenolic extraction from olive leaves (var. Serrana) by using power ultrasound, Innovat. Food Sci. Emerg. Tech. 17, 120-129.

Alagna F., Mariotti R., Panara F., Caporali S., Urbani S., Veneziani G., Esposto S., Taticchi A., Rosati A., Rao R., Perrotta G., Servili M., Baldoni L. (2012): Olive phenolic compounds: metabolic and transcriptional profiling during fruit development, BMC Plant Biol. 12, 162.

Aïachi Mezghani, M., Sahli, A., Jebari, A., 2007. Analysis and modeling of the vegetative growth of the olive tree (Olea europaea L.) in rainfall conditions. Fruits 61,45-56.

Aïachi Mezghani, M., Sahli, A., Labidi, F., Meddeb, K., Jebari, A., Ben El Hadj, S., 2008. Analysis of primary and secondary and modeling growth dynamics of oliveshoots (Olea europaea L.). J. Hortic. Sci. Biotechnol. 83, 411-419.

Al-Qarawi, A.A., Al-Damegh, M.A., El-Mougy, S.A. (2002). Effect of freeze dried extract of Olea europaea on pituitary-thyroid axis in rats. Phytotherapy Research, 16(3): 286-287.

Antolovich, M.; Prenzler, P.; Robards, K.; Ryan, D., (2000). Sample preparation in the determination of phenolic compounds in fruits. Analyst, 125, 989-1009.

Barranco, D., Fernandez, R., Rallo, L. (1998) in El Cultivo Del Olivo, Variedades y partones del cultivo del olivo, eds Barranco D., Fernandez-Escobar R., Rallo L. (Junta de Andalucia, Seville, Spain), pp 61-87.

Bisignano, G., Tomaino, A., Cascio, R., Crisafi, G., Uccella, N., Saija, A., (1999) . On the in vitro antimicrobial activity of oleuropein and hydroxytyrosol. Journal of pharmacy and pharmacology, 51:971-974.

Bongi, G. and A. Palliotti, (1994). Olive. In: Shaffer, B. anderson, P.C. (Eds.), Handbook of Environmental Physiology of Fruit Crops: 
Temperate Crops, vol. I. CRC Press, Boca Raton, FL, USA, pp: 165-187.

Briante R, Patumi M, Terenziani S, Bismuto E, Febbraio F., (2002). Olea europaea L. leaf extract and derivatives:antioxidant properties. J Agric Food Chem 50: 4934-4940.

Cimato, A. and P. Fiorino, (1986). Alternate bearing in Olive. 2. The effect of the fruits on the flower differentiation and mineral nutrition. Rivisitadella Ortoftorofrutticoltura Italiana, 69(6): 413429. Cited from Hort. Abst., 56: 8357.

Cuevas, J.; L. Rallo and H.F.Rapoport (1994): Crop load effects on floral quality in olive. Scientia Horticulturae: 59, 2, 123-130.

D’Andria, R., Tognetti, R., Morales-Sillero, A., Fernandez, J.E., Sebastiani, L., Troncoso,A., (2008). Deficit irrigation and fertigation practices in olive growing: conver-gences and divergences in two case studies. Plant Biosyst. 142, 138-148.

FAO. (2011). Country Pasture/Forage Resource Profiles, Publishing by Office of Knowledge Exchange, Research and Extension, FAO, Viale delle Terme di Caracalla, 00153 Rome, Italy, pg. 15 from 44.

Fernandez J E (2006). Irrigation management in olive. In: Biotechnology and Quality in Olive: Recent Advances in Olive Industry (Caruso T; Motisi A; Sebastiani L eds), pp. 295-305, Marsala, Italy.

Fernandez, J.E., Moreno, F., (1999). Water use by olive tree. J. Crop Prod. 2, 101-162

Giménez, C., E. Fereres, C. Ruz and F. Orgaz, (1997). Water relations and gas exchange of olive trees: diurnal and seasonal patterns of leaf water potential, photosynthesis and stomatal conductance. Acta Horticulturae, 449: 411-415.

Goldhamer D A (1999). Regulated deficit irrigation for California canning olives. Acta Horticulturae, 474, 369-372.

Guinda, A.; Albi, T.; Camino, M. C. P.; Lanzón, A. (2004). Supplementation of oils with oleanolic acid from the olive leaf (Olea europaea). Eur. J. Lipid Sci. Technol., 106, 22-26. 
Hayes JE, Stepanyan V, Allen P, O'Grady M.N., (2011). The effect of lutein, sesamol, ellagic acid and olive leaf extract on lipid oxidation and oxymyoglobin oxidation in bovine and porcine muscle model systems. Meat Sci 83: 201-208.

Herrero, M.; Temirzoda, T.N.; Segura-Carretero, A.; Quirantes, R.; Plaza, M.; Ibañez, E., (2011). New possibilities for the valorization of olive oil by-products. J. Chromatogr. A, 1218, 7511-7520.

Jakopic, J., Robert, V., Franci S, (2009). Extraction of phenolic compounds from green walnut fruits in different solvents, Acta Agriculture Slovenica, 93 - 1, maj str. 11-15.

Iniesta, F., Testi, L., Orgaz, F., Villalobos, F.J., (2009). The effects of regulated andcontinuous deficit irrigation on the water use, growth and yield of olivetrees. Eur. J. Agron. 25, 258-265.

Le Tutour, B., Guedon, D. (1992) Antioxidative activities of Olea Europea leaves and related phenolic compounds. Phytochemistry 31: 1173-1178.

Lee, O.H., Lee, B.Y., Lee, J., Lee, H.B., Son, J.Y., Park, C.S., Shetty, K., Kim, Y.C. (2009): Assessment of phenolics-enriched extract and fractions of olive leaves and their antioxidant activities, Biores. Tech. 100, 6107-6113.

M.A.L.R. (2015): Ministry of Agriculture and Land Reclamation Economic Affairs Sector - Agriculture Statics, fruit trees, Vol.(2)p 337-338.

Masmoudi-Charfi, C., Ben Mechlia, N., (2007). Characterization of young olive trees growth during the first six years of cultivation. Adv. Hortic. Sci. 21, 116-124.

Masmoudi-Charfi, C., Ben Mechlia, N., (2008). Changes in olive tree height growth during the first years of cultivation. Adv. Hortic. Sci. 22, 8-12.

Micol, V., Caturla, N., Pérez-Fons L., Mas V., Pérez L., et al. (2005). The olive leaf extract exhibits antiviral activity against viral 
haemorrhagic septicaemia rhabdovirus (VHSV). Antiviral Res 66:129-136.

Owen, R.W.; Haubner, R.; Würtele, G.; Hull, E.; Spiegelhalder, B.; Bartsch, H. (2004). Olives and olive oil in cancer prevention. Eur. J. Cancer Prev., 13, 319-326.

Palese, A.M., Nuzzo, V., Favati, F., Pietrafesa, A., Celano, G., Xiloyannis, C., (2010). Effectsof water deficit on the vegetative response, yield and oil quality of olive trees(Olea europaea L., cv. Coratina) grown under intensive cultivation. Sci. Hortic.125, 222-229.

Palomo MJ, Moreno F, Fernández JE, Díaz-Espejo A, Girón IF. (2002). Determining water consumption in olive orchards using the water balance approach. Agricultural Water Management 55: 15-35.

Pearce S.C., Dobersek-Urbanc S., (1967). The measurements of irregularity in growth and cropping. J. Hort. Sc. 42:295-305.

Peralbo-Molina, A., Luque de Castro, M.D. (2013): Potential of residues from the mediterranean agriculture and agrifood industry, Trends Food Sci. Tech. 32, 16-24.

Şahin, S.; Ahmed Malik, N.S.; Perez, J.L.; Brockington, J. E. (2012): Seasonal Changes of Individual Phenolic Compounds in Leaves of Twenty Olive Cultivars Grown in Texas, J. Agric. Sci. Technol. B, 2, 242-247.

Salama, A.M., El-Gendy, O. H., \& Ali, E. A. (2016). Olive "The blessed of desert tree" technical bulletin No. (2). Issued by General admin. of Ag. Culture.

Schieber, Andreas; Petra Keller and Reinhold Carle (2001). Determination of phenolic acids and flavonoids of apple and pear by high-performance liquid chromatography, Journal of Chromatography A, 910 265-273.

Somova L, Shode F, Ramnanan P, Nadar A (2003) Antihypertensive, antiatherosclerotic and antioxidant activity of triterpenoids isolated from Olea europaea, subspecies africana leaves. J Ethnopharmacol 84: 299-305. 
Tabera, J.; Guinda, A.; Ruiz-Rodriguez, A.; Senorans, J. F.; Ibanez, E.; Albi, T., Reglero, G. (2004). Countercurrent supercritical fluid extraction and fractionation of high-added-value compounds from a hexane extract of olive leaves. J. Agric. Food Chem., 52, 47744779 .

Tognetti R; d'Andria R; Lavini A; Morelli G, (2006). The effect of deficit irrigation on crop yield and vegetative development ofOlea europaea L. (cultivars Frantoio and Leccino). European Journal of Agronomy, 25, 356-364.

Tognetti R; d'Andria R; Morelli G; Alvino A, (2005). The effect of deficit irrigation on seasonal variations of plant water use in Olea europaea L. Plant and Soil, 273, 139-155.

Troncoso, A., Liñán, J., Cantos, M., Zárate, R. and Lavee, S. (1997). Influencia de la fertirrigación con urea sobre la disponibilidad de N-NO3 y el desarrollo del olivo. Fruticultura Profesional 88: 8387.

Tsimidou, M. Z., Papoti, V. T., (2010). "Bioactive ingredients in olive leaves. In: Olives and olive oil in health and disease prevention." Preedy V. P. and Watson R. R. (Eds), Elsevier Inc. 2010, Chapter 39, pp. 351-358.

Uccella N, Saija A (2001). Olive biophenols: functional effects on human wellbeing. Trends Food Sci. Technol. 11:357-363.

Vissers M.N., Zock P.L., Katan M.B. (2004): Bioavailability and antioxidant effects of olive oil phenols in humans: a review, Eur. J. Clin. Nutr. 58, 955-965.

Wiesman, Z., Ronen, A., Ankarion, Y., Novikov, V., Maranz, S., Chapagain, B., \& Avramovich, Z. (2002c). Effect of olive NutriVant on yield and quality of olives and oils. Acta Hort, 594, 557562 .

Wiesman, Z., Luber, M., Ronen, A., \& Markus, A. (2002d). Ferti-Vant a new nondestructive and long-lasting in vivo delivery system for foliar nutrients. Acta Hort, 594, 585-590. 
Wild, S. A., R. B .Corey, J. G. Lyer, and G. K. Voigt, (1985). Soil and Plant Analysis for Tree Culture. Oxford and IBH Publishing Co., New Delhi, India

\section{الملخص العربى}

\section{إدارة الرى التسميدى لتعظيم محتوى الأولوروبين فى أوراق الزيتون}

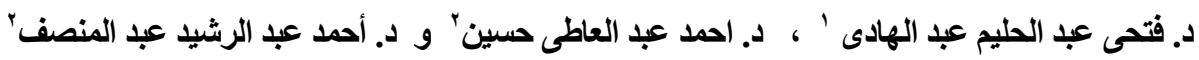

إجرى هذا البحث على أثجار الزيتون صنف شملالى عمر 10 عام ، عام ، خلال ثناث مواسم متتالية

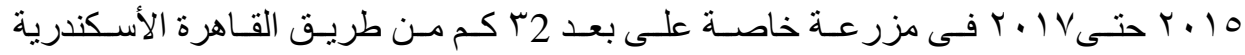

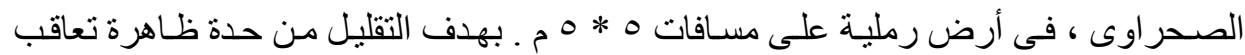

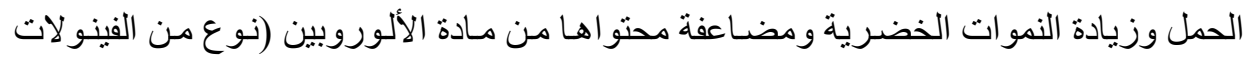

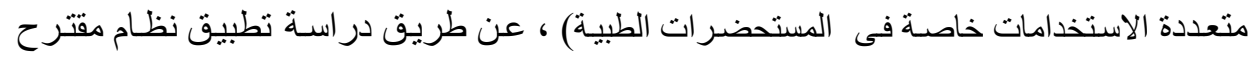

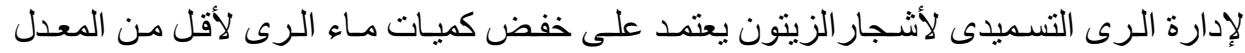

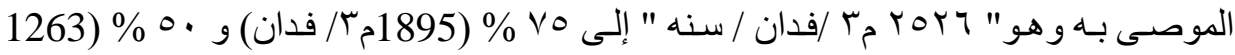

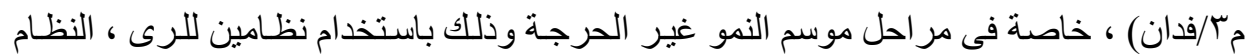

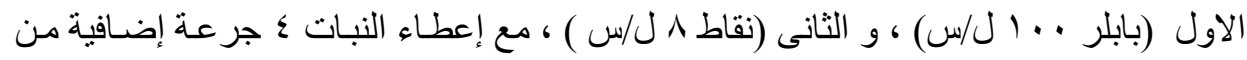

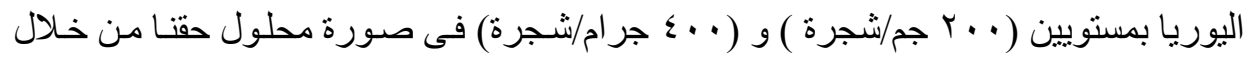

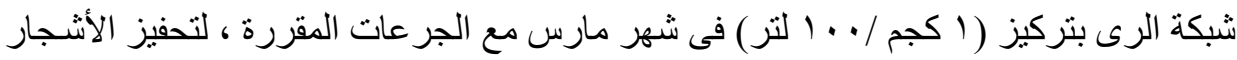

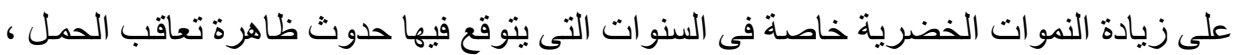

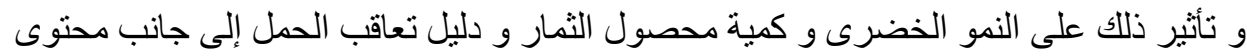

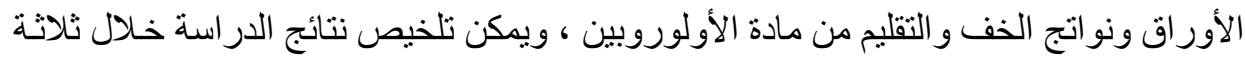

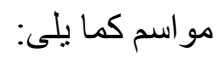

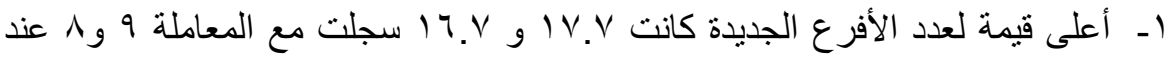

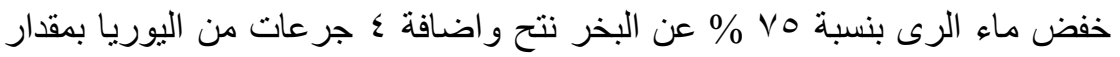

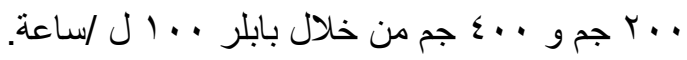

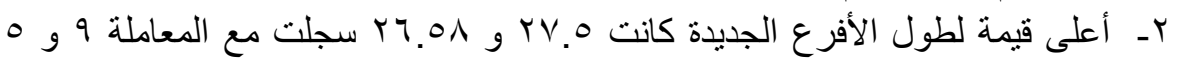

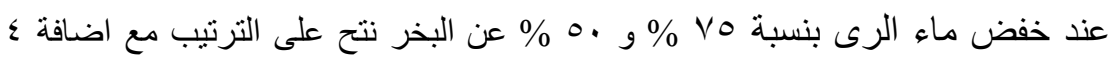

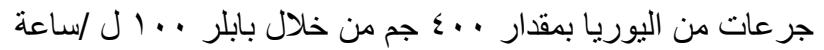

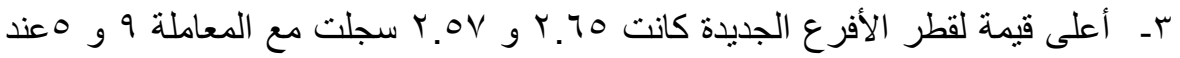

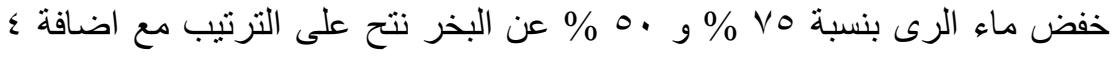

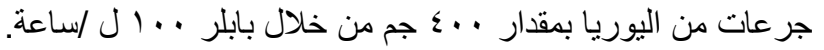

1 باحث بقسم نظم الهندسة الحيوية، معهد بحوث الهندة الزراعية، مركز البحوث الزراعية، الدقى ، الجيزة ، مصر.

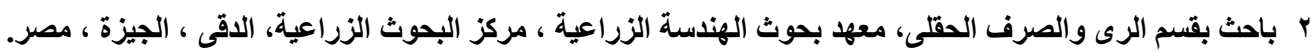


ع- ـ أعلى قيمة لعدد الأوراق على الأفرع الجديدة كانت 0.0 هب و بس سجلت مع المعاملة

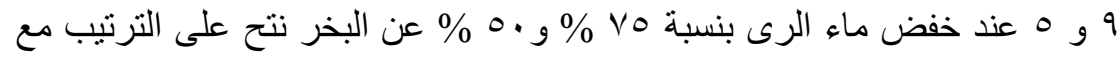

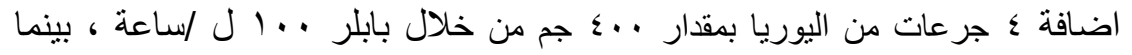

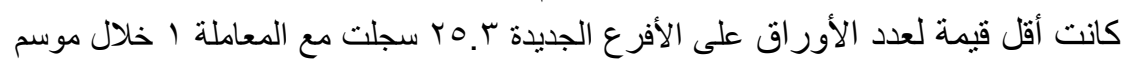
$r \cdot i \mathrm{~V}$

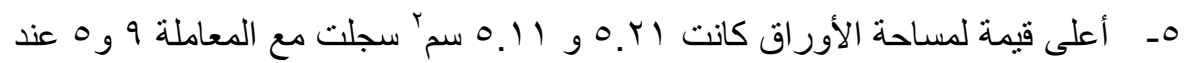

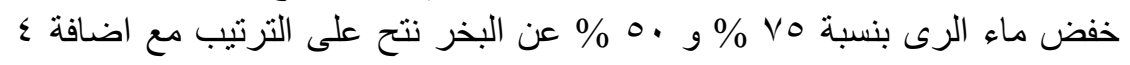

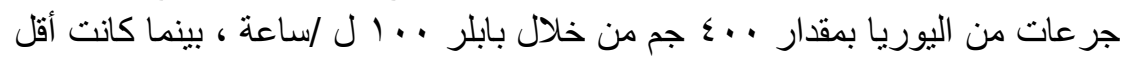

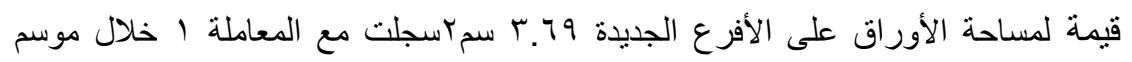
$r .1 \mathrm{~V}$

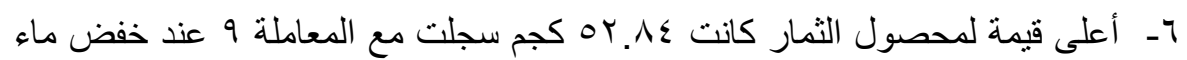

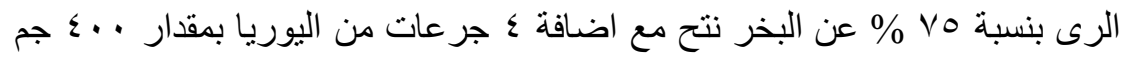

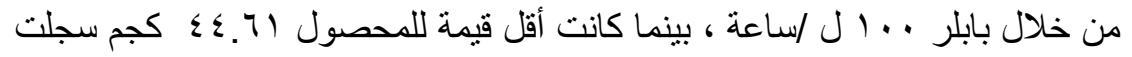

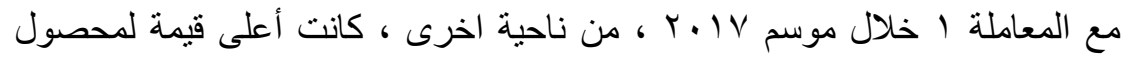

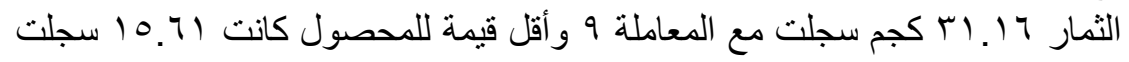

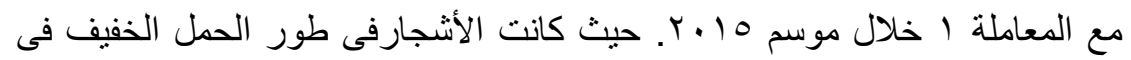
ذلك العام.

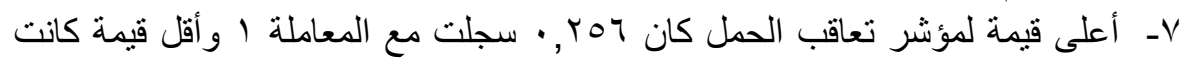

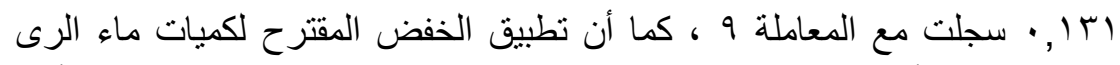

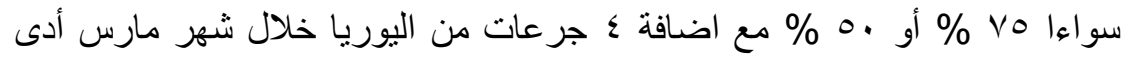

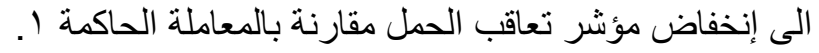

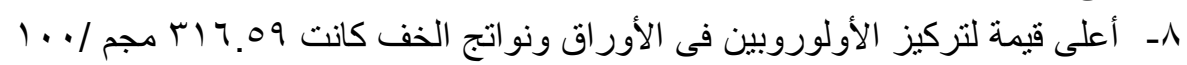

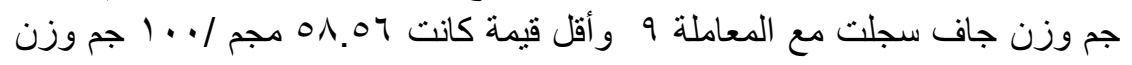

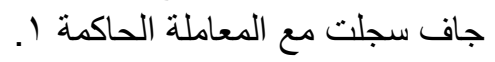

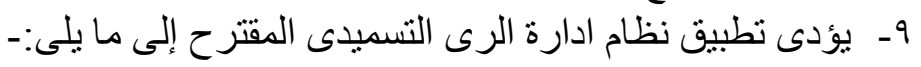

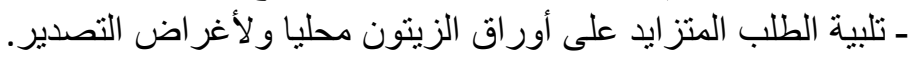

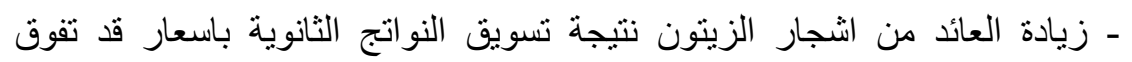

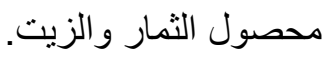

